\title{
Показники фізичної та військово- професійної підготовленості курсантів факультету протиповітряної оборони сухопутних військ ХНУПС ім. І. Кожедуба
}

\author{
Володимир Перевозник \\ Володимир Паєвський \\ Катерина Максимова
}

Харківська державна академія фізичної культури, Харків, Україна

Мета: визначити динаміку показників фізичної та військово-професійної підготовленості курсантів факультету Протиповітряної оборони Сухопутних військ (ППО СВ) ХНУПС ім. І. Кожедуба.

Матеріал і методи: теоретичний аналіз науково-методичної літератури, педагогічне тестування, методи математичної статистики.

Результати: визначена динаміка показників фізичної та військово-професійної підготовленості курсантів факультету ППО СВ ХНУПС ім. І. Кожедуба. За час експериментального періоду, який тривав один (2019-2020) навчальний рік, у якому брали участь курсанти третього курсу факультету ППО СВ відбулося поліпшення середніх результатів за тестами, що характеризує швидкість рухів, витривалість, швидкісно-силові здібності і власне силові здібності. Підвищення рівня фізичної підготовленості сприяло підвищенню рівня військово-професійної підготовленості курсантів. У результаті кореляційного аналізу виявлено взаємозв'язок надійності у діях курсантів в умовах навчань з рівнем розвитку різних сторін фізичної підготовленості.

Висновки: отримана динаміка кількісних показників фізичної та військово-професійної підготовленості курсантів та здійснений кореляційний аналіз даних, що дає підставу для корегування навчального процесу курсантів факультету ППО СВ у напрямку удосконалення фізичної підготовки з урахуванням військово-професійної діяльності.

Ключові слова: курсанти, фізична підготовленість, військово-професійна підготовленість, показники.

\section{Вступ}

Сучасні вимоги, які спрямовані на покращення підготовки спеціалістів різних галузей, повною мірою стосуються й підготовки військових кадрів для Збройних сил України (ЗСУ). Одним з основних етапів становлення професійної майстерності майбутніх офіцерів - спеціалістів найвищого рангу - $є$ навчання у військових закладах вищої освіти (ВЗВО). Курсанта потрібно не тільки якісно готувати до військової професії за спеціальними дисциплінами, а й забезпечити йому високий рівень фізичної готовності до бойової діяльності, перенесення значних фізичних навантажень, нервово-психічних напружень в екстремальних ситуаціях $[4,13]$.

У складних умовах ведення бойових дій від військовослужбовця потрібно вимагати не тільки високий рівень професійної підготовленості за своєю військовою спеціальністю, а й уміння діяти як самостійна «бойова одиниця", вміло здійснювати маневр вогнем і рухом. Успішність вирішення цих завдань безпосередньо залежить від уміння військовослужбовців володіти своєю зброєю, володіти високим рівнем розвитку військово-прикладних навичок, фізичних і морально-психологічних якостей. Од- нак сьогоднішній досвід ведення бойових дій у зоні АТО та інших локальних конфліктах, результати перевірок бойової готовності військових частин і підрозділів свідчать про недостатній рівень фізичної підготовленості особового складу, i, насамперед, витривалості, навченості в ефективному використанні особистої зброї, метанні гранат, здатності долати природні та штучні перешкоди та виконувати інші військово-професійні прийоми і дії $[1,3,5]$.

У той же час вирішення проблеми ефективного підвищення боєздатності військовослужбовців засобами і методами фізичної підготовки, викладеними раніше в Настанові з фізичної підготовки (НФП-2014) виявляється не завжди достатнім. Існує необхідність в розробці спеціальних, науково-обгрунтованих засобів і методів фізичної підготовки для підвищення боєздатності військовослужбовців у відповідності зі специфічними вимогами їх воєнно-професійної діяльності. На необхідність проведення спеціальної (зокрема фізичної) підготовки військовослужбовців до ведення бойових дій вказують ряд авторів $[7,15]$. Досвід бойової підготовки і результати наукових досліджень свідчать про те, що важливим і найбільш ефективним засобом вирішення завдань спеціальної фізичної підготовки військовослужбовців є за- 
стосування фізичних вправ і видів спорту, які найбільше позитивно наближені за своїм впливом на фізичні й професійні дії військовослужбовців $[1,4,7]$.

Значні, граничні фізичні і нервово-психічні навантаження, які доводиться витримувати особовому складові у процесі сучасних воєнних дій, істотно знижують боєздатність військовослужбовців. Найвиразніше це виявляється у погіршенні показників ведення вогню і здійснення маневру на полі бою, у зниженні швидкості і точності дій при використанні бойової техніки і зброї. Ступінь зниження боєздатності військовослужбовців під час виконання бойових завдань визначається величиною i характером навантажень, спеціальними уміннями, рівнем фізичної підготовленості, фізичного розвитку, станом здоров'я та іншими чинниками $[9,14]$. У Збройних силах провідних держав НАТО розробляються концепції фізичної готовності, спрямовані на завчасний розвиток у особового складу фізичних та психологічних якостей та військово-прикладних навичок, які забезпечують виконання бойових завдань у різноманітних, у тому числі й екстремальних умовах [8].

Військовослужбовці з високим рівнем розвитку сили, витривалості, швидкості, спритності в умовах бойових дій переважають за різними показниками військово-професійної діяльності військовослужбовців, у яких рівень цих якостей нижчий (Ю.А. Бородін, 2002; В.В. Паєвський, О.А. Шевченко, 2004). Дослідники Ю.С. Фіногенов (2009), С.В. Романчук (2012) доводять, що військово-професійне навчання (опанування певного обсягу військовоприкладних, спеціальних навичок) не може проходити успішно без достатнього розвитку фізичних якостей, які необхідні для вміння швидко пересуватися на місцевості, долати різні перешкоди, плавати (зокрема в обмундируванні зі зброєю), ходити на лижах [10, 11, 12].

Мета дослідження - визначити динаміку показників фізичної та військово-професійної підготовленості курсантів факультету Протиповітряної оборони Сухопутних військ ХНУПС ім. І. Кожедуба.

\section{Матеріал і методи дослідження}

Здійснювалось педагогічне тестування показників фізичної і військово-професійної підготовленості курсантів факультету Протиповітряної оборони Сухопутних військ упродовж 2019-2020 навчального року, за допомогою якого досліджувалась динаміка цих показників. Методи дослідження: теоретичний аналіз науково-методичної літератури, педагогічне тестування, методи математичної статистики.

\section{Результати дослідження}

У ході занять з курсантами факультету Протиповітряної оборони Сухопутних військ використовувалися методи вибіркового впливу з застосуванням повторного та інтервального методів тренування, фронтального і потокового способів виконання вправ. При проведенні естафет і рухливих ігор використовувався змагальний метод.

Побудова занять не відрізнялася від загальноприйнятої. Кожне заняття складалося з підготовчої, основної і заключної частин. Принцип підбору вправ для підготовчої і заключної частин залишався традиційним. Послідовність проходження програми в основному відповідала програмі фізичної підготовки курсантів факультету Протиповітряної оборони Сухопутних військ. Основною відмінністю було те, що $40 \%$ часу кожного заняття відводилося на вирішення навчальних питань, а 60\% часу використовувалося для розвитку фізичних якостей, необхідних для військово-професійної діяльності курсантів факультету ППО СВ. Варто підкреслити, що значний обсяг роботи на витривалість виконувався в процесі спортивно-масової та самостійної роботи. 3 часу, що відводився на розвиток фізичних якостей, використовувалися вправи, що переважно розвивали м'язи нижніх кінцівок $-50 \%$ часу, м'язів тулуба - 30\% і м'язів рук - 20\% часу.

Крім цього на заняттях використовувалися поперемінно вправи на розвиток м'язів-розгиначів і згиначів тулуба. Меншою мірою були задіяні м'язи плечового поясу. Також варто вважати використання стрибків максимальної інтенсивності (зістрибування зі значних підвищень більше 2,5 м). Слід також зазначити часте використання спеціальних бігових вправ, особливо на початковому етапі, що дозволило підготувати опорно-руховий апарат до наступних максимальних навантажень стрибкової роботи. Застосування всього комплексу вправ дозволило здійснити спрямованість на переважний розвиток найбільш професійно важливих груп м'язів із забезпеченням на базі різнобічного їхнього розвитку необхідної якісної спрямованості або у бік сили, або ж у бік швидкості. За час експериментального періоду, який тривав один (2019-2020) навчальний рік, та у якому брали участь курсанти третього курсу факультету Протиповітряної оборони Сухопутних військ, відбулося поліпшення середніх результатів за тестами, що характеризує швидкість рухів, витривалість, швидкісно-силові здібності і власне силові здібності (табл. 1).

3 п'яти тестів фізичної підготовленості, при виконанні яких у роботу утягується велика кількість м'язових груп, істотні зміни $(p<0,05)$ у курсантів відбулися за чо-

Таблиця 1

Динаміка показників фізичної підготовленості курсантів факультету ППО СВ на початку і наприкінці експериментального періоду (n=25)

\begin{tabular}{|c|c|c|c|c|c|}
\hline № & Досліджувані показники & $\begin{array}{l}\text { Початок } \\
\overline{X_{1}} \pm m_{1}\end{array}$ & $\begin{array}{l}\text { Кінець } \\
X_{2} \pm m_{2}\end{array}$ & $\mathrm{t}$ & $\mathrm{p}$ \\
\hline 1. & Біг на 100 м, с & $14,2 \pm 0,5$ & $13,6 \pm 0,6$ & 0,83 & $>0,05$ \\
\hline 2. & $\begin{array}{l}\text { Загальна контрольна вправа на смузі } \\
\text { перешкод, с }\end{array}$ & $143,4 \pm 4,4$ & $128,3 \pm 4,3$ & 2,45 & $<0,05$ \\
\hline 3. & Стрибок угору з місця, см & $49,2 \pm 1,9$ & $56,3 \pm 1,5$ & 3,00 & $<0,01$ \\
\hline 4. & Біг на $3000 \mathrm{M}, \mathrm{c}$ & $710,5 \pm 13,5$ & $665,2 \pm 9,5$ & 2,75 & $<0,05$ \\
\hline 5. & Підтягування на поперечині, к-ть разів & $13,2 \pm 1,2$ & $18,7 \pm 1,1$ & 3,37 & $<0,01$ \\
\hline
\end{tabular}




\section{СЛОБОЖАНСЬКИЙ НАУКОВО-СПОРТИВНИЙ ВІСНИК}

Таблиця 2

Динаміка показників рівня військово-професійної підготовленості курсантів факультету ПпО СВ на початку і наприкінці експериментального періоду $(\mathrm{n}=25)$

\begin{tabular}{|c|c|c|c|c|c|}
\hline № & Досліджувані показники & $\begin{array}{l}\text { Початок } \\
\overline{X_{1}} \pm m_{1}\end{array}$ & $\begin{array}{l}\text { Кінець } \\
\overline{X_{2}} \pm m_{2}\end{array}$ & $\mathrm{t}$ & $\mathrm{p}$ \\
\hline 1. & $\begin{array}{lccc}\text { Посадка у у } & \text { бойову } & \text { машину } \\
\text { (бронетранспортер), с } & \end{array}$ & $27,7 \pm 0,5$ & $26,3 \pm 0,4$ & 2,19 & $<0,05$ \\
\hline 2. & $\begin{array}{l}\text { Висадка } 3 \text { бойової } \\
\text { (бронетранспортера), с }\end{array}$ & $14,7 \pm 0,3$ & $13,8 \pm 0,3$ & 2,12 & $<0,05$ \\
\hline 3. & $\begin{array}{l}\text { Викопування і маскування окопів для } \\
\text { бойової техніки (3У-23), с }\end{array}$ & $7817,0 \pm 54,6$ & $7657,9 \pm 53,2$ & 2,09 & $<0,05$ \\
\hline 4. & $\begin{array}{l}\text { Перекочування ЗУ-23 силами обслуги на } \\
\text { відстань } 100 \text { м із бойового положення } 3 \\
\text { приведенням у бойове положення на } \\
\text { новій вогневій позиції (середньо- } \\
\text { пересічена місцевість), с }\end{array}$ & $235,5 \pm 8,9$ & $212,3 \pm 5,8$ & 2,19 & $<0,05$ \\
\hline 5. & $\begin{array}{l}\text { Заряджання бойової машини “Стріла- } \\
\text { 10М” чотирма ракетами, с }\end{array}$ & $137,7 \pm 2,3$ & $130,6 \pm 2,4$ & 2,14 & $<0,05$ \\
\hline 6. & $\begin{array}{l}\text { Розряджання бойової машини “Стріла- } \\
\text { 10M”, с }\end{array}$ & $135,9 \pm 1,0$ & $133,9 \pm 1,0$ & 1,41 & $>0,05$ \\
\hline 7. & $\begin{array}{l}\text { Приготування до стрільби з різних } \\
\text { положень (лежачи, з коліна, стоячи, з-за } \\
\text { укриття) при діях у пішому порядку, с }\end{array}$ & $8,3 \pm 0,6$ & $6,6 \pm 0,5$ & 2,07 & $<0,05$ \\
\hline 8. & Розряджання магазину АК-74, с & $19,2 \pm 1,4$ & $15,3 \pm 1,3$ & 2,07 & $<0,05$ \\
\hline 9. & 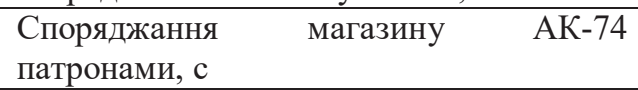 & $40,1 \pm 2,7$ & $32,8 \pm 2,3$ & 2,08 & $<0,05$ \\
\hline 10. & $\begin{array}{l}\text { Стрільба з ПМ по нерухомій цілі вдень } \\
\text { (вправа №1), бали }\end{array}$ & $19,2 \pm 3,2$ & $21,6 \pm 3,5$ & 0,51 & $>0,05$ \\
\hline 11. & Метання гранати Ф-1 на дальність, м & $35,5 \pm 2,1$ & $36,6 \pm 1,8$ & 0,42 & $>0,05$ \\
\hline 12. & $\begin{array}{l}\text { Метання гранати } \\
\text { точність, бали }\end{array}$ & $26,9 \pm 3,1$ & $36,8 \pm 3,4$ & 2,15 & $<0,05$ \\
\hline
\end{tabular}

тирьма тестами (загальна контрольна вправа на смузі перешкод, стрибок угору з місця, біг на 3000 м, підтягування на поперечині). Таким чином, відбулися значні поліпшення результатів за тими напрямками удосконалення фізичної підготовленості, які у результаті експерименту були визначені як основні.

Поліпшення надійності у діях військовослужбовців базується на підвищенні рівня фізичної працездатності в звичайних умовах. У таблиці 2 показана динаміка показників рівня військово-професійної підготовленості курсантів факультету ППО СВ.

Так, з дванадцяти тестів військово-професійної підготовленості, істотні зміни $(p<0,05)$ у курсантів відбулися за дев'ятьма тестами (посадка, висадка у бойову машину (бронетранспортер), викопування і маскування окопів для бойової техніки (ЗУ-23), перекочування ЗУ-23 силами обслуги на відстань 100 м із бойового положення з приведенням у бойове положення на новій вогневій позиції (середньопересічена місцевість), заряджання бойової машини "Стріла-10М" чотирма ракетами, приготування до стрільби з різних положень (лежачи, з коліна, стоячи, із-за укриття) при діях у пішому порядку, розряджання, споряджання магазину АК-74, метання гранати Ф-1 з місця на точність.

у той же час позитивна динаміка відбулася і в показниках тестів розряджання бойової машини «Стріла10M», стрільба з ПМ по нерухомій цілі вдень (вправа
№1), метання гранати Ф-1 на дальність, однак, вірогідність не була виявлена ( $p>0,05)$. Таким чином, підвищення рівня фізичної підготовленості сприяло підвищенню рівня військово-професійної підготовленості курсантів. У результаті кореляційного аналізу (табл. 3) виявлено взаємозв'язок надійності у діях курсантів в умовах навчань з рівнем розвитку різних сторін фізичної підготовленості. Аналіз кореляційної матриці дозволив детермінувати фактори надійності військово-професійної діяльності. Факторами у даному випадку є різні сторони фізичної підготовленості військовослужбовців. Кореляційний аналіз дозволив визначити ступінь значущості фізичної підготовленості у зв'язку з проявом якостей: сили в різних проявах, швидкості, витривалості, що забезпечують надійність у діях курсантів ППО СВ.

Щільність зв'язку між показниками надійності в діях і тестах, що відображають рівень розвитку сили, швидкісно-силових якостей, швидкісних якостей, витривалості, показує високу залежність рівня боєздатності від усіх сторін фізичної підготовленості курсантів. Однак $є$ відмінність у рівні кореляцій, що дозволяє говорити про ступінь значущості розвитку певних рухових здібностей для забезпечення надійності у діях курсантів. Найбільш високі кореляційні зв'язки виявлено у показниках боєздатності на навчаннях і результатах бігу на 100 м, а також у стрибках угору з місця, що відображають рівень розвитку швидкісних і швидкісно-силових можливостей. У резуль- 
Таблиця 3

Кореляційний взаємозв'язок показників спеціальної працездатності з показниками фізичної підготовленості курсантів (n=25)

\begin{tabular}{|c|c|c|c|c|c|c|}
\hline \multirow[b]{2}{*}{ № } & \multirow[b]{2}{*}{$\begin{array}{l}\text { Показники спеціальної } \\
\text { працездатності }\end{array}$} & \multicolumn{5}{|c|}{ Фізична підготовленість } \\
\hline & & 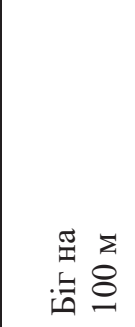 & 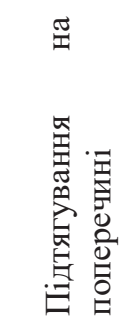 & 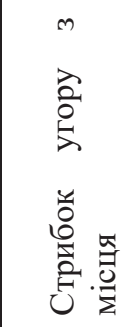 & 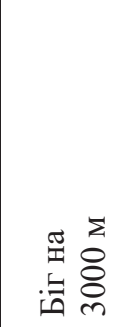 & 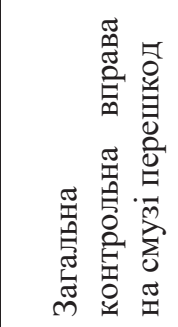 \\
\hline 1. & Посадка у бойову машину (бронетранспортер), с & 0,54 & 0,38 & $-0,42$ & 0,31 & 0,50 \\
\hline 2. & Висадка з бойової машини (бронетранспортера), с & 0,61 & 0,40 & 0,50 & 0,43 & 0,59 \\
\hline 3. & $\begin{array}{l}\text { Викопування і маскування окопів для бойової техніки } \\
(3 У-23), \text { с }\end{array}$ & 0,58 & 0,41 & 0,26 & 0,23 & 0,24 \\
\hline 4. & $\begin{array}{lll}\text { Перекочування } 3 У-23 \text { силами обслуги на відстань } 100 \\
\text { м із бойового положення } 3 & \text { приведенням в } \\
\text { положениове } \\
\text { (середньопересічена місцевість), с } & \\
\end{array}$ & 0,59 & $-0,18$ & 0,39 & 0,35 & 0,53 \\
\hline 5. & $\begin{array}{l}\text { Заряджання бойової машини “Стріла-10М” чотирма } \\
\text { ракетами, с }\end{array}$ & $-0,63$ & 0,49 & 0,49 & $-0,11$ & $-0,39$ \\
\hline 6. & Розряджання бойової машини “Стріла-10М”, с & $-0,53$ & 0,46 & 0,22 & $-0,37$ & $-0,51$ \\
\hline 7. & $\begin{array}{l}\text { Приготування до стрільби з різних положень (лежачи, } 3 \\
\text { коліна, стоячи, 3-за укриття) при діях у пішому } \\
\text { порядку, с }\end{array}$ & $-0,47$ & $-0,21$ & 0,20 & 0,01 & $-0,30$ \\
\hline 8. & Розряджання магазину, с & 0,60 & $-0,31$ & $-0,38$ & 0,34 & 0,42 \\
\hline 9. & Споряджання магазину АК-74 патронами, с & 0,61 & $-0,38$ & $-0,48$ & 0,54 & 0,57 \\
\hline 10. & $\begin{array}{l}\text { Стрільба з ПМ по нерухомій цілі вдень (вправа №1), } \\
\text { бали }\end{array}$ & $-0,18$ & $-0,36$ & $-0,10$ & 0,11 & $-0,38$ \\
\hline 11. & Метання гранати Ф-1 на дальність, м & 0,21 & $-0,35$ & 0,11 & 0,19 & 0,12 \\
\hline 12. & Метання гранати Ф-1 з місця на точність, бали & 0,16 & 0,34 & 0,21 & 0,04 & 0,14 \\
\hline
\end{tabular}

татах бігу на 100 м рівень чотирьох коефіцієнтів кореляції з дванадцяти на рівні 0,60 і вище. У стрибках угору з місця також чотири коефіцієнти кореляції мають величини 0,42-0,50. Трохи нижчі кореляційні зв'язки результатів у підтягуванні на поперечині, що відображають власне силові можливості, із окремими показниками спеціальної працездатності, що знаходяться на рівні 0,40-0,49. Дещо вищі коефіцієнти кореляції спостерігаються між показниками надійності у спеціальних діях і результатами загальної контрольної вправи на смузі перешкод, що характеризує рівень розвитку швидкісної витривалості. Так, п'ять коефіцієнтів кореляції -3 першого року занять у ВЗВО необхідно акцентувати увагу на використанні вправ, які розвивають найбільш професійно важливі групи м'язів, що сприяє морфо-функціональним перебудовам в організмі під впливом військово-професійної діяльності. Упродовж експериментального періоду за показниками тестів фізичної підготовленості у курсантів відбулися істотні зміни $(p<0,05)$ за чотирма тестами з п'яти. Таким чином, відбулися значні поліпшення результатів за тими напрямками удосконалення фізичної підготовленості, які у результаті експерименту були визначені як основні.

3 дванадцяти тестів військово-професійної підготовленості істотні зміни $(p<0,05)$ у курсантів відбулися за дев'ятьма тестами. У той же час позитивна динаміка відбулася і в показниках тестів розряджання бойової машини «Стріла-10М», стрільби з ПМ по нерухомій цілі вдень (вправа №1), метання гранати Ф-1 на дальність, однак, вірогідність не була виявлена ( $>>0,05)$. Таким чином, підвищення рівня фізичної підготовленості сприяло підвищенню рівня військово-професійної підготовленості курсантів.

Перспективи подальших досліджень вбачаємо у вивченні питання удосконалення фізичної підготовленості за рахунок спортивних та рухливих ігор.

Конфлікт інтересів. Автори заявляють, що відсутній конфлікт інтересів, який може сприйматись таким, що може завдати шкоди неупередженості статті.

Джерела фінансування. Ця стаття не отримала фінансової підтримки від державної, громадської або комерційної організації. 


\section{Список посилань}

1. Афонін В., Глебко С. (2003), «Динаміка фізичної підготовленості курсантів за період навчання у Львівському інституті», Фізична підготовка військовослужбовців : матеріали відкритої наук.-метод. конф. К., С. 3-6.

2. Бородін Ю. А. Романчук В. М., Романчук С. В. (2003), Організація та зміст фізичної підготовки курсантів у період початкової військової підготовки: метод. реком. Житомир : ЖВІРЕ, 44 с.

3. Глазунов С. И. (2007), «Проблемы мотивации к физическому совершенствованию офицеров Вооруженных Сил Украины», Педагогіка, психологія та медико-біологічні проблеми фізичного виховання і спорту, №1. С. 16-20.

4. Єдинак Г. А. (2012), «До питання про вдосконалення системи оцінювання фізичної підготовленості військовослужбовців Збройних сил України», Physical education, sport and health culture in modern society, 4 (20). C. $276-280$.

5. Лойко О. М. (2014), «Тенденции изменения содержания физической подготовки военнослужащих механизированных подразделений сухопутных войск Вооруженных Сил Украины», Актуальные проблемы огневой, тактико-специальной и профессионально-прикладной физической підготовки: материалы II междунар. конф. Могилев : Могилев. институт МВД, С. 252258.

6. Паевский В. В., Шевченко О. А. (2004), «Роль физической подготовки в совершенствовании задач и функциональных особенностей учебно-боевой деятельности личного состава подразделений ПВО Сухопутных войск», Педагогіка, психологія та медико-біологічні проблеми фізичного виховання і спорту, №9. С. 53-62.

7. Ролюк О. В. (2016), «Вдосконалення фізичної підготовки військовослужбовців засобами прикладних видів спорту», Науковий часопис Національного педагогічного університету імені М.П.Драгоманова. Серія №15. "Науково-педагогічні проблеми фізичної культури /фізична культура і спорт», Випуск 01(68)16. С. 74-77.

8. Романчук С., Романчук В. (2010), «Фізична підготовка в сухопутних військах збройних сил провідних держав НАТО», Молода спортивна наука України, Вип. 14. Т. 2. С. 205 - 209.

9. Романчук С. В. (2012), Фізична підготовка курсантів військових навчальних закладів Сухопутних військ Збройних Сил України: монографія. Л.: АСВ, 366 с.

10. Фіногенов Ю. С. (2003), «Професіоналізація Збройних Сил України і деякі питання перебудови системи фізичної підготовки військовослужбовців», Фізична підготовка військовослужбовців: матеріали наук. -метод. конф. К., С. 40-43.

11. Шевченко О. А. (2007), «Специальная направленность поэтапного формирования физических качеств военных специалистов ПВО Сухопутных войск», Физическое воспитание студентов творческих спеціальностей, №1. С. 161-167

12. Шлямар І. (2015), «Динаміка фізичної підготовленості військовослужбовців військової служби за контрактом механізованих підрозділів», Молода спортивна наука України, Вип. 19, т. 2. С. 320 - 324

13. Huang J., Wang Y., Cheng X., Zhou L., Wu Z. (2012), «Current status of medical support in military operations other than war in domestic and overseas», Journal of Medical Colleges of PLA, Vol. 27(6). P. 343-350.

14. Kelley J. (1996), «Brilliant Warriors», Joint Forces Quarterly. P. 104-110.

15. Lisowski V. O., Mihuta I. Yu. (2013), «Importance of coordination skills essential psychophysical demonstrated competencies as a military specialists», Phisical Education of Students. Vol. 6. P. 38-42.

Стаття надійшла до редакції: 02.12.2020 р.

Опубліковано: 21.12.2020 р.

Аннотация. Владимир Перевозник, Владимир Паевский, Екатерина Максимова. Показатели физической и военно-профессиональной подготовленности курсантов факультета Противовоздушной обороны Сухопутных войск ХНУВС им. И. Кожедуба. Цель: определить динамику показателей физической и военно-профессиональной подготовленности курсантов факультета Противовоздушной обороны Сухопутных войск (ПВО СВ) ХНУПС им. И. Кожедуба. Материал и методы: теоретический анализ научно-методической литературы, педагогическое тестирование, методы математической статистики. Результаты: определена динамика показателей физической и военно-профессиональной подготовленности курсантов факультета ПВО СВ ХНУПС им. И. Кожедуба. За время экспериментального периода, который длился один (2019-2020) учебный год, в котором приняли участие курсанты третьего курса факультета ПВО СВ произошло улучшение средних результатов по тестам, характеризующим скорость движений, выносливость, скоростно-силовые способности и собственно силовые способности. Повышение уровня физической подготовленности способствовало повышению уровня военно-профессиональной подготовленности курсантов. В результате корреляционного анализа выявлена взаимосвязь надежности в действиях курсантов в условиях обучения с уровнем развития различных сторон физической подготовленности. Выводы: полученная динамика количественных показателей физической и военно-профессиональной подготовленности курсантов и осуществленный корреляционный анализ данных дает основание для коррекции учебного процесса курсантов факультета ПВО СВ в направлении совершенствования физической подготовки с учетом военно-профессиональной деятельности.

Ключевые слова: курсанты, физическая подготовленность, военно-профессиональная подготовленность, показатели.

Abstract. Volodymyr Perevoznik, Volodymyr Paievskyi, Kateryna Maxymova. Indicators of physical and militaryprofessional readiness of the cadets of the Air Defense Faculty of the Ground Forces of the KhNUVS named after I. Kozhedub. Purpose: to determine the dynamics of indicators of physical and military-professional readiness of the cadets of the Air Defense Faculty of the Ground Forces of the KhNUPS named after I. Kozhedub. Material and methods: theoretical analysis of scientific and methodological literature, pedagogical testing, methods of mathematical statistics. Results: the dynamics of indicators of physical and military-professional readiness of cadets of the Air Defense Faculty of the Ground Forces of the KhNUPS named after I. Kozhedub. During the experimental period, which lasted one (2019-2020) academic year, in which the third-year cadets of the Air Defense Faculty of the Ground Forces took part, there was an improvement in the average results on tests characterizing the speed of movement, endurance, speed-strength abilities and proper strength abilities. The increase in the level of physical readiness contributed to the increase in the level of military-professional readiness of the cadets. As a result of the correlation analysis, the interrelation of reliability in the actions of cadets in the conditions of exercises with the level of development of various sides of physical fitness was revealed. Conclusions: the obtained dynamics of quantitative indicators of physical and military-professional readiness of cadets and the carried out correlation analysis of the data provide the basis for adjusting the educational process of the cadets of the Air Defense Faculty of the Ground Forces in the direction of improving physical training, taking into account military-professional activity.

Keywords: cadets, physical fitness, military professional preparedness, indicators.

Перевозник, В., Паєвський, В., Максимова, К. (2020), «Показники фізичної та військово-професійної підготовленості курсантів факультету протиповітряної оборони сухопутних військ ХНУПС ім. І. Кожедуба» 


\section{References}

1. Afonin, V., Hlebko, S. (2003), «Dynamics of physical fitness of cadets during the period of study at the Lviv Institute», Fizychna pidhotovka viiskovosluzhbovtsiv : materialy vidkrytoi nauk.-metod. konf. K., pp. 3-6. (in Ukr.).

2. Borodin, Yu. A. Romanchuk, V. M., Romanchuk, S. V. (2003), Orhanizatsiia ta zmist fizychnoi pidhotovky kursantiv u period pochatkovoi viiskovoi pidhotovky [Organization and content of physical training of cadets in the period of initial military training]: metod. rekom. Zhytomyr : ZhVIRE, 44 p. (in Ukr.).

3. Glazunov, S. I. (2007), «Problems of motivation for physical improvement of officers of the Armed Forces of Ukraine», Pedahohika, psykholohiia ta medyko-biolohichni problemy fizychnoho vykhovannia i sportu, №1. pp. 16-20. (in Russ.).

4. ledynak, H. A. (2012), "On the issue of improving the system of assessment of physical fitness of servicemen of the Armed Forces of Ukraine», Physical education, sport and health culture in modern society, 4 (20), pp. 276-280. (in Ukr.).

5. Loyko, O. M. (2014), «Trends in the content of physical training of military personnel of mechanized units of the ground forces of the Armed Forces of Ukraine", Aktualnyie problemyi ognevoy, taktiko-spetsialnoy i professionalno-prikladnoy fizicheskoy pldgotovki: materialyi II mezhdunar. konf. Mogilev: Mogilev. institut MVD, pp. 252258 (in Russ).

6. Paevskiy, V. V., Shevchenko, O. A. (2004), «The role of physical training in improving the tasks and functional features of the combat training activities of the personnel of the air defense units of the Ground Forces", Pedahohika, psykholohiia ta medykobiolohichni problemy fizychnoho vykhovannia i sportu, №9. pp. 53-62 (in Russ.).

7. Roliuk, O. V. (2016), «Improving the physical training of servicemen by means of applied sports», Naukovyi chasopys Natsionalnoho pedahohichnoho universytetu imeni M.P.Drahomanova. Seriia №15. «Naukovo-pedahohichni problemy fizychnoi kultury /fizychna kultura i sport», Vypusk 01(68)16. pp. 74-77. (in Ukr.).

8. Romanchuk, S., Romanchuk, V. (2010), «Physical training in the ground forces of the armed forces of leading NATO countries», Moloda sportyvna nauka Ukrainy, Vyp. 14. T. 2. pp. 205-209 (in Ukr.).

9. Romanchuk, S. V. (2012), Fizychna pidhotovka kursantiv viiskovykh navchalnykh zakladiv Sukhoputnykh viisk Zbroinykh Syl Ukrainy [Physical training of cadets of military educational institutions of the Land Forces of the Armed Forces of Ukraine]: monohrafiia. L. : ASV, 366 p. (in Ukr.).

10. Finohenov, Yu. S. (2003), «Professionalization of the Armed Forces of Ukraine and some issues of restructuring the system of physical training of servicemen", Fizychna pidhotovka viiskovosluzhbovtsiv: materialy nauk.-metod. konf. K., pp. 40-43. (in Ukr.).

11. Shevchenko, O. A. (2007), «Special orientation of the phased formation of physical qualities of military specialists of the Air Defense of the Ground Forces», Fizicheskoe vospitanie studentov tvorcheskih spetslalnostey, No.1. pp. 161-167 (in Russ.).

12. Shliamar, I. (2015), "Dynamics of physical fitness of military servicemen under the contract of mechanized units», Moloda sportyvna nauka Ukrainy, Vyp. 19, t. 2. pp. 320 - 324 (in Ukr.).

13. Huang J., Wang Y., Cheng X., Zhou L., Wu Z. (2012), «Current status of medical support in military operations other than war in domestic and overseas», Journal of Medical Colleges of PLA, Vol. 27(6). P. 343-350 (in Eng.).

14. Kelley J. (1996), «Brilliant Warriors», Joint Forces Quarterly. P. 104-110 (in Eng.).

15. Lisowski V. O., Mihuta I. Yu. (2013), «Importance of coordination skills essential psychophysical demonstrated competencies as a military specialists», Phisical Education of Students. Vol. 6. P. 38-42 (in Eng.).

Received: 02.12.2020.

Published: 21.12.2020.

\section{Відомості про авторів / Information about the Authors}

Перевозник Володимир Іванович: к. фіз.вих., доцент; Харківська державна академія фізичної культури: вул. Клочківська, 99, м. Харків, 61058, Україна.

Перевозник Владимир Иванович: к.физ.восп., доцент; Харьковская государственная академия физической культуры: ул. Клочковская, 99, г. Харьков, 61058, украина.

Volodymyr Perevoznik: PhD (Physical Education and Sport), Associate Professor; Kharkiv StateAcademy of Physical Culture: Klochkivska 99, Kharkiv, 61058, Ukraine.

ORCID.ORG/0000-0001-6798-1497

E-mail: v.perevoznik60@mail.ru

Паєвський Володимир Валерійович: к.фіз.вих., доцент; Харківська державна академія фізичної культури: вул. Клочківська, 99. м. Харків, 61058, Україна.

Паевский Владимир Валерьевич: к. физ.восп., доцент; Харьковская государственная академия физической культуры: ул. Клочковская, 99, г.Харьков, 61058, Украина.

Volodymyr Paievskyi: PhD (physical education and sport), Assosiate Professor; Kharkiv State Academy of Physical Culture: Klochkivska str. 99, Kharkiv, 61058, Ukraine.

ORCID.ORG/0000-0002-9068-1422

E-mail: v.paevskiy1971@gmail.com

Максимова Катерина Володимирівна: Харківська державна академія фізичної культури: вул. Клочківська, 99, м. Харків, 61058, Україна.

Максимова Екатерина Владимировна: Харьковская государственная академия физической культуры: ул. Клочковская, 99, г. Харьков, 61058, Украина.

Kateryna Maxymova: Kharkiv State Academy of Physical Culture: Klochkivska str. 99, Kharkiv, 61058, Ukraine.

ORCID.ORG/0000-0001-6556-1659

E-mail: okateryna2014@gmail.com 